\title{
UJI EFEKTIFITAS DEKOK BUNGA BELIMBING WULUH (Averrhoa bilimbi) SEBAGAI ANTIMIKROBA TERHADAP BAKTERI Salmonella Typhi SECARA IN VITRO
}

\section{(THE EFFICACY TEST OF PICKLE FRUIT FLOWER (Averrhoa bilimbi L.) DECOC AS AN ANTIMICROBIAL AGENT TO Salmonella typhi IN VITRO)}

\author{
Alhamfaib Ardananurdin*, Sri Winarsih ${ }^{* *}$, Mahono Widayat ${ }^{* * *}$ \\ ${ }^{*}$ Program Studi Kedokteran FK Unibraw \\ ** Laboratorium Mikrobiologi FK Unibraw \\ *** Laboratorium Parasitologi FK Unibraw
}

\begin{abstract}
Salmonella typhi is causative agent of typhoid fever and its still a main health problem in Indonesia. Pickle fruit flower had been recognized by Indonesian society that have usefulness to cure various diseases. Pickle fruit flower contain active substance of saponin, polifenol and flavonoids. The experimental laboratoric aim was to know the efficacy of pickle fruit flower decoct as an antimicrobial agent to Salmonella typhi in vitro by using tube dilution method and continued by streaking on Bismuth Sulfite Agar. The concentration of pickle fruit flower decoct were 0\%; $5 \%$; 7.5\%; 10\%; 12.5\%; and 15\% and the sample of Salmonella typhi were 4 isolates derived from different patients. The concentration of Salmonella typhi was $10^{4} \mathrm{cell} / \mathrm{ml}$. The result from the experiment was MIC at $10 \%$ and MBC at $12,5 \%$ concentration. The statistic analysis showed that pickle fruit flower decoct can reduce Salmonella typhi growth in vitro significantly (Anova, $p=0.000$ ) and there was a correlation between increasing concentration of pickle fruit flower with the reduced amount of colonies (correlation, $R=-0.795$ ). From this study we can conclude that pickle fruit flower decoct has an antimicrobial effect to Salmonella typhi fondly of MIC and MBC at 10\% and $12.5 \%$ respectively.
\end{abstract}

Key word: The pickle fruit flower, Salmonella typhi, Minimal Inhibition Concentration (MIC), Minimal Bactericidal Concentration (MBC).

\section{PENDAHULUAN}

Penyakit saluran pencernaan hingga saat ini masih menjadi ancaman masyarakat dan seringkali menimbulkan kematian, terutama pada anak-anak. Ada tiga penyakit saluran pencernaan yang hingga saat ini masih jadi ancaman yakni diare, demam tifoid, dan cacingan (1).

Demam tifoid masih merupakan masalah kesehatan yang serius di negara berkembang termasuk di Indonesia (2). Kasus demam tifoid di Indonesia, masih cukup tinggi berkisar antara 354-810 / 100.000 penduduk pertahun bersifat sporadik endemik dan timbul sepanjang tahun. Dari penelitian retrospektif yang dilakukan di Palembang selama periode 5 tahun (1990-1994) didapatkan sebanyak 83 kasus ( $21,5 \%$ ) penderita demam tifoid dengan hasil biakan darah Salmonellapositif dari penderita yang dirawat dengan klinis demam tifoid (3). Selain itu, demam tifoid menempati urutan no 8 sebagai penyakit penyebab kematian utama di Indonesia (4).

Penatalaksanaan demam tifoid secara medis sampai saat ini masih menganut trilogi penatalaksaan demam tifoid yaitu antimikroba, istirahat dan diet (3). Namun bakteri penyebab demam tifoid ini telah resisten terhadap obat-obatan konvensional.

Untuk itu perlu difikirkan pengobatan alternatif ataupun pengobatan pendamping yang efektif dan efisien serta aman dan cukup murah akan tetapi tetap berorientasi pada standar pelayanan kesehatan yang telah ada. Pengobatan pendamping yang dimaksud antara lain adalah dengan menggunakan ramuan tradisional yaitu dengan menggunakan bahan-bahan tradisional.

Jurnal Kedokteran Brawijaya, Vol. XX, No.1, April 2004.

Korespondensi : Sri Winarsih; Lab. Mikrobiologi FK Unibraw; JI. Veteran Malang-65145; telp (0341) 580993, 567192 fax (0341)564755.
Belimbing wuluh dikenal cukup baik di masyarakat Indonesia. Buahnya yang asam membuat belimbing wuluh kerap digunakan sebagai bahan campuran dalam berbagai masakan tradisional. Belimbing wuluh (Averrhoa bilimbi) memiliki rasa yang khas dan memberikan aroma tertentu pada masakan (5).

Manfaat belimbing wuluh ternyata tak hanya sebatas itu. Tanaman ini memiliki berbagai khasiat obat yang bisa sangat membantu. Bunga belimbing wuluh selain sebagai obat batuk, juga bisa digunakan sebagai obat pegal linu, gondongan, rematik, sariawan, jerawat, panu, darah tinggi, dan sakit gigi (5). Selain itu tanaman ini juga dapat menyembuhkan sakit perut, diare, gangguan pencernaan, radang rectum $(6,7)$.

Belum ada bukti ilmiah apakah bunga belimbing wuluh sebagai ramuan obat khususnya dapat digunakan sebagai pengobatan alternatif untuk mengobati penyakit demam tifoid.

Untuk itu perlu dilakukan suatu penelitian untuk mendapatkan dasar teoritis dan bukti-bukti ilmiah tentang penggunaan bunga belimbing wuluh dalam mengobati penyakit demam tifoid. Salah satu cara yang dapat dilakukan adalah dengan melakukan penelitian mengenai efektivitas bunga belimbing wuluh sebagai antimikroba terhadap bakteri Salmonella typhi penyebab penyakit demam tifoid. Tujuan umum dari penelitian ini adalah untuk mengetahui efektivitas penggunaan dekok bunga belimbing wuluh sebagai antimikroba terhadap bakteri Salmonella typhi. Sedangkan tujuan khusus dalam penelitian ini adalah untuk mengetahui nilai KHM (Kadar Hambat Minimum) dan KBM (Kadar Bunuh Minimum) dari dekok bunga belimbing wuluh terhadap bakteri Salmonella typhi serta untuk mengetahui hubungan antara jumlah koloni yang tumbuh pada pemberian konsentrasi yang berbeda dari dekok bunga belimbing wuluh. Manfaat yang dapat diambil dari penelitian ini adalah memberikan informasi kepada masyarakat bahwa bunga belimbing wuluh dapat digunakan sebagai pengobatan alternatif 
terhadap penyakit demam tifoid, ditemukannya bahan antimikroba yang murah dan terjangkau oleh seluruh lapisan masyarakat dan memberikan dasar pengembangan ilmu pengetahuan tentang manfaat tanaman obat dalam hal ini bunga belimbing wuluh bagi kesehatan.

Hipotesis dari penelitian ini bahwa bunga belimbing wuluh (Averrhoa bilimbi L.) memiliki daya antimikroba terhadap Salmonella typhi dan pemberian konsentrasi berbeda bunga belimbing wuluh mempengaruhi pertumbuhan koloni Salmonella typhi yaitu semakin tinggi konsentrasi bunga Belimbing wuluh akan menyebabkan pertumbuhan koloni bakteri Salmonella typhi semakin rendah.

\section{METODE}

\section{Lokasi dan Waktu Penelitian}

Penelitian dilaksanakan di Laboratorium Mikrobiologi

Fakultas Kedokteran Universitas Brawijaya Malang, dengan waktu pelaksanaan penelitian pada bulan April 2004.

\section{Desain, Populasi dan Sampel Penelitian}

Penelitian ini dilaksanakan dengan rancang bangun penelitian eksperimental laboratorik. Uji efek antimikroba dekok bunga belimbing wuluh (Averhoa bilimbi L.) terhadap bakteri Salmonella typhi dilakukan secara in vitro, menggunakan metode dilusi tabung yang dilanjutkan dengan penggoresan pada medium padat.

Pada penelitian ini digunakan 4 (empat) isolat bakteri Salmonella typhi yang berasal dari penderita yang dimiliki oleh Laboratorium Mikrobiologi Fakultas Kedokteran Universitas Brawijaya Malang.

\section{Alat dan Bahan}

Alat yang digunakan adalah: Erlenmeyer, Panci, Kompor gas, Kapas, Aluminium foil, Ose, Tabung steril 25 buah, Incubator, Mikroskop, Mikropipet, mikrotip steril, Spektrofotometer, Bunsen, korek api, Spidol permanen, dan Colony counter sedangkan bahan yang digunakan adalah Bunga belimbing wuluh $50 \mathrm{gram}$, Aqudest steril $100 \mathrm{ml}$, Alkohol 96\%, Dekok bunga belimbing wuluh, Medium BSA padat, Nutrien Broth, Aquadest steril.

\section{Pembuatan Sediaan Dekok Bunga Belimbing Wuluh (9)}

Pembuatannya dengan cara bunga belimbing wuluh ditimbang seberat 50 gram kemudian dimasukkan ke dalam erlenmeyer yang telah diisi alkohol $96 \%$, diaduk dan didiamkan selama 10 menit, dari tabung erlenmeyer kemudian dimasukkan ke dalam tabung erlenmeyer yang telah diisi dengan aquadest $100 \mathrm{ml}$. Tabung Erlenmeyer tersebut kemudian dimasukkan ke dalam air mendidih selama 15 menit. Setelah 15 menit kemudian diangkat dan didiamkan sampai suhu dibawah $40{ }^{\circ} \mathrm{C}$. Air Bunga belimbing wuluh dipipet dan ditampung di dalam labu ukur steril kemudian ditambahkan aquadest steril sampai volume $100 \mathrm{ml}$, sehingga diperoleh konsentrasi awal dekok bunga belimbing wuluh $50 \% \mathrm{~b} / \mathrm{v}$.

\section{Pembuatan Suspensi Uji Bakteri Salmonella typhi}

Dilakukan identifikasi ulang terhadap isolat bakteri dengan cara menanam pada medium Mc Conkey (tidak berwarna), agar TSI (Alk/AS, gas (-), $\mathrm{H}_{2} \mathrm{~S} \oplus$ ), serta pewarnaan gram (bentuk batang Gram negatif). Sediakan bakteri Salmonella typhi yang telah diukur kepadatan selnya menggunakan spektrofotometer (OD $0,08-0,1$ pada $\lambda=600 \mathrm{~nm}$ ), OD tersebut setara dengan konsentrasi $10^{8}$ bakteri/ml (10). Konsentrasi bakteri Salmonella typhi sebesar $10^{8}$ bakteri/ml tersebut kemudian diencerkan dengan broth nutrient sampai menjadi konsentrasi $2 \times 10^{4}$ bakteri/ml.

\section{Pengujian Bahan}

Sediakan hasil dekok bunga belimbing wuluh konsentrasi $50 \%$ dan suspensi bakteri Salmonella typhi konsentrasi $2 \times 10^{4}$ yang telah dipersiapkan sebelumnya. Sediakan 6 tabung reaksi, untuk perlakuan $30 \% ; 25 \% ; 20 \% ; 15 \% ; 10 \%$ dan $0 \%$. Tabung 1 diisi $0,4 \mathrm{ml}$ aquadest steril dan $0,6 \mathrm{ml}$ sediaan dekok bunga belimbing wuluh, sehingga konsentrasi menjadi $30 \%$. Tabung 2 diisi dengan 0,5 aquadest steril dan $0,5 \mathrm{ml}$ sediaan dekok bunga belimbing wuluh, sehingga konsentrasi menjadi $25 \%$. Tabung 3 diisi $0,6 \mathrm{ml}$ aquadest steril dan $0,4 \mathrm{ml}$ sediaan dekok bunga belimbing wuluh, sehingga konsentrasi menjadi $20 \%$. Tabung 4 diisi $0,7 \mathrm{ml}$ aquadest steril dan $0,3 \mathrm{ml}$ sediaan dekok bunga belimbing wuluh, sehingga konsentrasi menjadi $15 \%$. Tabung 5 diisi $0,8 \mathrm{ml}$ aquadest steril dan $0,2 \mathrm{ml}$ sediaan dekok bunga belimbing wuluh, sehingga konsentrasi menjadi $10 \%$. Tabung 6 diisi $1 \mathrm{ml}$ aquadest steril dan $0 \mathrm{ml}$ sediaan dekok bunga belimbing wuluh, sehingga konsentrasi menjadi $0 \%$. Ulangi pengisian tabung 1 sampai 6 sebanyak empat kali dan beri label untuk masing masing isolat. Lalu tambahkan $1 \mathrm{ml}$ suspensi bakteri Salmonella typhi konentrasi $2 \times 10^{4}$ untuk masing-masing isolat dalam tabung 1, 2, 3, 4, 5, dan 6 sesuai dengan label isolat masing-masing. Sehingga konsentrasi akhir dekok bunga belimbing wuluh dalam tiap tabung adalah $15 \% ; 12,5 \% ; 10 \%$; $7,5 \%$; dan $5 \%$. Sedangkan konsentrasi akhir suspensi bakteri Salmonella typhi adalah $10^{4}$ bakteri/ml (10). Campuran pada tabung 8 diambil 1 ose dan ditanam pada medium BSA. Koloni yang tumbuh dihitung sebagai inokulum awal bakteri. Lalu Inkubasi selama $18-24$ jam pada suhu $37^{\circ} \mathrm{C}$. Amati kekeruhan tabung untuk menentukan KHM. Kemudian masing-masing tabung perlakuan sebanyak 1 ose dilakukan penggoresan pada media Bismuth Sulfite Agar (BSA), beri label sesuai isolat dan konsentrasinya. Inkubasi selama $18-24$ jam pada suhu $37^{\circ} \mathrm{C}$. Amati dan hitung hasil pertumbuhan koloni bakteri Salmonella typhi.

\section{Analisis Data}

Analisis data dilakukan dengan menggunakan fasilitas SPSS for Windows 12 pada derajat kepercayaan $95 \%(\alpha=0,05)$. Untuk uji beda antar perlakuan dipilih metode Anova satu arah dan untuk mengetahui besarnya hubungan dan pola hubungan antar perlakuan dipilih uji Korelasi-Regresi.

\section{HASIL}

Pengamatan Kekeruhan Larutan Dalam Tabung Tabel 1. Hasil pengamatan kekeruhan pada tabung broth

\begin{tabular}{|c|c|c|c|c|c|c|c|}
\hline \multirow{2}{*}{ Isolat } & \multicolumn{6}{|c|}{ Konsentrasi Dekok Bunga Belimbing Wuluh } & Kontrol \\
\cline { 2 - 7 } & $\mathbf{0 \%}$ & $\mathbf{5 \%}$ & $\mathbf{7 , 5 \%}$ & $\mathbf{1 0 \%}$ & $\mathbf{1 2 , 5 \%}$ & $\mathbf{1 5 \%}$ & Bahan \\
\hline I & Sangat keruh & keruh & keruh & jernih & jernih & jernih & Jernih \\
\hline II & Sangat keruh & keruh & Keruh & jernih & Jernih & jernih & Jernih \\
\hline III & Sangat keruh & Keruh & Keruh & Jernih & Jernih & Jernih & Jernih \\
\hline IV & Sangat keruh & Keruh & Keruh & Jernih & jernih & Jernih & Jernih \\
\hline
\end{tabular}


Hasil yang didapat pada pengamatan menunjukkan warna tabung menjadi merah. Data Kadar Hambat Minimum (KHM) ditunjukkan pada konsentrasi $10 \%$ dimana tabung mulai tampak jernih. Kemudian dilakukan penanaman hasil uji dilusi tabung pada seri agar padat BSA yang telah disiapkan untuk mengetahui Kadar Bunuh Minimum (KBM) dan untuk mengetahui pengaruh konsentrasi bunga belimbing wuluh terhadap pertumbuhan koloni bakteri Salmonella typhi. dari isolat yang berbeda, yang semuanya diberi perlakuan konsentrasi yang sama. Masing-masing isolat ini diberi label isolat 1, 2, 3, dan 4.

Berdasarkan gambar 2 dapat dilihat bahwa dengan meningkatnya konsentrasi, maka jumlah pertumbuhan koloni bakteri Salmonella typhi pada tiap-tiap isolat menjadi berkurang. Kadar Bunuh Minimum (KBM) bunga belimbing wuluh terhadap Salmonella typhi adalah pada konsentrasi $12,5 \%$.

Tabel 2. Hasil penghitungan jumlah koloni Salmonella typhi pada pemberian berbagai konsentrasi dekok bunga belimbing wuluh

\begin{tabular}{|c|c|c|c|c|c|c|c|}
\hline \multirow{2}{*}{ Isolat } & \multicolumn{6}{|c|}{ Konsentrasi } & \multirow{2}{*}{ Jumlah Inokulum awal } \\
\hline & $0 \%(\mathrm{KK})$ & $5 \%$ & $7,5 \%$ & $10 \%$ & $12,5 \%$ & $15 \%$ & \\
\hline $\mathrm{I}$ & 265302054 & 30009474 & 684 & 0 & 0 & 0 & 43263 \\
\hline II & 258778233 & 31314204 & 6156 & 1368 & 0 & 0 & 47196 \\
\hline III & 343587906 & 31966569 & 1710 & 0 & 0 & 0 & 41724 \\
\hline IV & 276175089 & 30879351 & 855 & 0 & 0 & 0 & 44118 \\
\hline Rata-rata & 285960820,5 & 31042399,5 & 2351,25 & 342 & 0 & 0 & 44075,25 \\
\hline SD & 39082473,57 & 820870,85 & 2573,90 & 684 & 0 & 0 & 2304,27 \\
\hline
\end{tabular}

\section{Pengamatan dan Penghitungan Jumlah Koloni}

Pada metode penelitian disebutkan bahwa selain suspensi bakteri uji ditambahkan pada tabung yang diberi perlakuan konsentrasi dekok bunga belimbing wuluh, juga langsung dilakukan penanaman (penggoresan) pada medium BSA untuk mengetahui jumlah koloni/inokulum awal. Inokulum awal ini digunakan untuk menentukan KBM dimana telah disebutkan bahwa KBM merupakan konsentrasi terendah yang memungkinkan pertumbuhan hanya $<0,1 \%$ dari jumlah inokulum awal, sehingga $0,1 \%$ dari jumlah inokulum awal data diatas sebesar 44 koloni (11). Pada konsentrasi 10\% didapatkan hanya isolat II yang mengalami pertumbuhan bakteri sedangkan isolat I, III, dan isolat IV tdak mengalami pertumbuhan koloni bakteri. Pada konsentrasi $10 \%$ belum dapat dikatakan sebagai KBM dikarenakan rata-rata jumlah pertumbuhan koloninya sebesar 342 (>44 koloni) atau dengan kata lain pertumbuhan koloninya $>0,1 \%$ dari jumlah inokulum awal.

Pada diagram batang pada gambar 1 terdapat enam perlakuan pemberian dekok bunga belimbing wuluh pada beberapa konsentrasi yaitu konsentrasi $0 \% ; 5 \% ; 7,5 \%$; $10 \%$;
Dari hasil Uji One-Way Anova didapatkan bahwa dari data pertumbuhan jumlah koloni tersebut mempunyai perbedaan yang cukup bermakna $(p=0,000)$. Untuk melihat perbedaan jumlah koloni yang tumbuh pada perlakuan konsentrasi yang berbeda dilakukan uji post hoc seperti pada tabel 3.

Hasil uji post hoc Duncan didapatkan bahwa pada konsentrasi $0 \%$ dan $5 \%$ menunjukkan perbedaan bermakna dengan semua konsentrasi. Sedangkan konsentrasi 7,5\%; 10\%; 12,5\%; dan 15\% tidak berbeda bermakna.

Dari hasil uji Korelasi menunjukkan adanya korelasi atau hubungan yang kuat $(-0,795)$ serta bermakna $(p=0,000)$ antara konsentrasi dan jumlah koloni. Koefisien korelasi > 0,5 atau mendekati 1 menunjukkan adanya korelasi yang kuat. Sedangkan tanda (-) menunjukkan adanya korelasi yang berlawanan (berbanding terbalik) antara konsentrasi dengan jumlah koloni, yang artinya semakin besar konsentrasi maka semakin sedikit jumlah koloni yang tumbuh. Dari hasil uji regresi didapatkan bahwa pola hubungan antara konsentrasi dan koloni lebih mengarah pada pola regresi cubic dengan nilai $R^{2}=0,98242$ yang artinya bahwa $98,242 \%$ data hasil penelitian terletak pada garis pola regresi cubic. Persamaan garis regresi dari penelitian ini

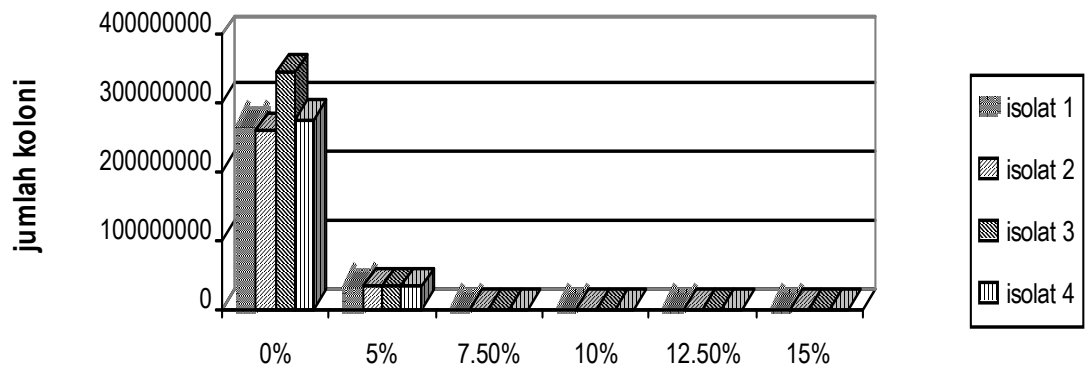

konsentrasi

Gambar 1. Diagram batang jumlah koloni berdasarkan perlakuan konsentrasi bunga belimbing wuluh

12,5\%; dan 15\%. Terdapat empat isolat bakteri Salmonella typhi adalah y $=-237971 X^{3}+7900386 X^{2}-84094660 X+285637441$, 


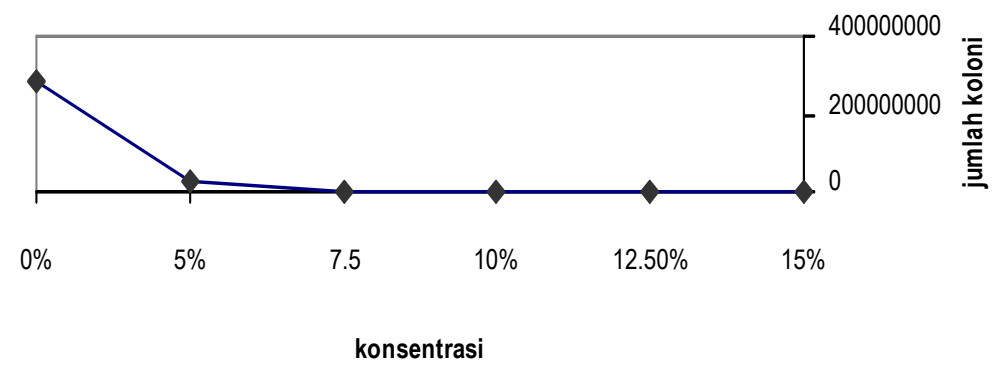

\section{Gambar 2. Grafik rata-rata jumlah koloni berdasarkan perlakuan konsentrasi bunga Belimbing Wuluh}

dimana y adalah jumlah koloni Salmonella typhi sedangkan $x$ adalah konsentrasi dekok bunga belimbing wuluh.

Tabel 3 Hasil uji post hoc Duncan

\begin{tabular}{|} 
Koloni \\
\begin{tabular}{|c|c|c|c|c|}
\hline \multirow{2}{*}{ Konsentrasi } & \multirow{2}{*}{$\mathbf{N}$} & \multicolumn{3}{|c|}{ Subset untuk $\mathbf{\alpha}=\mathbf{0 , 0 5}$} \\
\cline { 3 - 5 } & & $\mathbf{1}$ & $\mathbf{2}$ & $\mathbf{3}$ \\
\hline 15,00 & 4 & 0,0000 & & \\
12,50 & 4 & 0,0000 & & \\
10,00 & 4 & 342,000 & & \\
7,50 & 4 & 2351,250 & & \\
5,00 & 4 & & 31042399,50 & \\
0,00 & 4 & & & 285960820,5 \\
\hline
\end{tabular}
\end{tabular}

\section{PEMBAHASAN}

Penelitian ini dilakukan untuk mengetahui efektifitas dekok bunga belimbing wuluh (Averhoa bilimbi) sebagai antimikroba terhadap bakteri Salmonella typhi secara in vitro. Metode yang digunakan dalam penelitian ini adalah metode dilusi tabung untuk menentukan adanya Kadar Hambat Minimum (KHM) dan Kadar Bunuh Minimum (KBM).

Sediaan dekok bunga belimbing wuluh yang digunakan dalam penelitian ini dibuat dari bunga belimbing wuluh yang masih segar. Bunga belimbing wuluh dapat dengan mudah diperoleh dari pekarangan sekitar rumah sehingga diharapkan penerapan hasil penelitian ini lebih mudah bagi masyarakat. Pada penelitian ini dibuat konsentrasi awal dekok bunga belimbing wuluh sebesar $50 \%$ yang berarti dalam 50 gram bahan bunga belimbing wuluh ditambahkan aquadest steril sebanyak $100 \mathrm{ml}$.

Dalam penelitian ini digunakan 4 isolat bakteri Salmonella typhi yang berasal dari penderita demam tifoid dan disimpan oleh Laboratorium Mikrobiologi Fakultas Kedokteran Universitas Brawijaya Malang. Kepadatan bakteri Salmonella typhi yang digunakan dalam penelitian ini adalah $10^{4}$ bakteri/ml. 10 Kepadatan sel bakteri diukur dengan menggunakan alat spektrofotometer pada panjang gelombang $600 \mathrm{~nm}$.

Penelitian ini menggunakan enam konsentrasi dekok bunga belimbing wuluh yang berbeda yaitu $0 \% ; 5 \% ; 7,5 \% ; 10 \%$; $12,5 \%$; dan $15 \%$ sebagai rentang konsentrasi yang dianggap mewakili. Keenam konsentrasi tersebut diperoleh berdasarkan percobaan pendahuluan (eksplorasi awal) yang telah dilakukan sebelummya sehubungan dengan belum diketemukannya referensi yang mendukung mengenai konsentrasi dekok bunga belimbing wuluh yang dipakai dalam penelitian.

Setelah dilakukan penelitian dengan metode dilusi tabung, didapatkan hasil bahwa Kadar Hambat Minimum (KHM) terhadap bakteri Salmonella typhi ditunjukkan oleh larutan dekok bunga belimbing wuluh dengan konsentrasi $10 \%$. Pada konsentrasi $10 \%$ larutan dekok bunga belimbing wuluh tampak jernih dan bila dibandingkan dengan kontrol bahan menunjukkan kejernihan yang sama. Pada konsentrasi yang lebih rendah yaitu pada konsentrasi $7,5 \% ; 5 \% ; 0 \%$ menunjukkan kekeruhan dengan tingkat yang berbeda. Sedangkan pada konsentrasi $12,5 \%$, dan $15 \%$ larutan tampak jernih seperti pada konsentrasi $10 \%$ dan kontrol bahan.

Kadar Bunuh Minimum (KBM) diperoleh dari penanaman perparat dilusi tabung pada Bismuth Sulfite Agar (BSA). Pada penelitian ini diperoleh Kadar Bunuh Minimum (KBM) adalah pada konsentrasi $12,5 \%$ dimana sudah tidak terdapat petumbuhan koloni pada BSA setelah diinkubasikan selama 18-24 jam pada suhu $37^{\circ} \mathrm{C}$. Pada konsentrasi $10 \%$ belum dapat dikatakan sebagai KBM dikarenakan masih ada isolat bakteri yang menunjukkan jumlah koloni cukup besar (Isolat II, 1368 koloni).

Hasil dari penelitian ini ternyata dapat membuktikan hipotesis yang diajukan, yaitu dekok bunga Belimbing Wuluh memiliki daya antimikroba terhadap bakteri Salmonella typhi (Anova, $p=0,000 ; R=-0,749 ; R^{2}=0,982$ ). Daya antimikroba bunga belimbing wuluh ini disebutkan oleh karena adanya bahanbahan aktif yang terkandung di dalamnya yang berperan utama dalam menghambat pertumbuhan maupun membunuh bakteri Salonella typhi. Bahan aktif tersebut diantaranya adalah saponin, polifenol dan flavonoids $(6,12)$.

Saponin adalah senyawa penurun tegangan permukaan yang kuat yang menimbulkan busa bila dikocok dalam air. Sifat saponin menyerupai sabun (bahasa latin sapo berarti sabun) (13). Saponin bekerja sebagai antimikroba dengan mengganggu stabilitas membran sel bakteri sehingga menyebabkan sel bakteri lisis (14).

Polifenol bekerja melalui penghambatan enzim mikroorganisme oleh bagian senyawa yang teroksidasi, kemungkinan melalui reaksi dengan gugus sulfhidril atau melalui interaksi yang non spesifik dengan protein mikroorganisme. Selain itu polifenol juga dapat menyebabkan denaturasi protein bakteri (15).

Flavonoid berefek antimikroba melalui kemampuan untuk membentuk kompleks dengan protein ekstraseluler dan protein yang dapat larut serta dengan dinding sel bakteri (13). 
Dalam penelitian ini digunakan metode dekok yaitu preparasi atau proses penyaringan bahan aktif bunga belimbing wuluh menggunakan aquadest steril dengan pemanasan di atas penangas air, sehingga bahan-bahan aktif yang berperan sebagai antimikroba yang terkandung dalam bunga belimbing wuluh kemungkinan merupakan bahan aktif yang mempunyai sifat larut dalam air yaitu senyawa saponin, flavonoid dan polifenol (13).

Peneliti lain juga telah menguji daya antimikroba bunga belimbing wuluh terhadap bakteri lain, diantaranya adalah bakteri Pseudomonas aeruginosa, Escherichia coli (E.coli), Methicillin Resistant Stapylococcus aureus (MRSA) $(16,17)$. Didapatkan hasil bahwa KHM dan KBM bakteri Pseudomonas aeruginosa pada konsentrasi $10 \%$ sedangkan KHM untuk bakteri E.coli dan MRSA didapatkan pada konsentrasi 15\%. KBM bakteri MRSA terdapat pada konsentrasi $25 \%$, sedangkan untuk bakteri E.coli tidak ditemukan KBM. Hal ini kemungkinan disebabkan adanya variasi sifat yang khas pada masing-masing bakteri tersebut. Berdasarkan dari hasil penelitian peneliti lain yang menguji efektifitas bunga belimbing wuluh terhadap bakteri diatas ternyata bunga belimbing wuluh cukup efektif sebagai antimikroba untuk bakteri Salmonella typhi, E.coli, MRSA dan Pseudomonas aeruginosa yang mewakili dari golongan Gram (+) dan Gram (-). Namun masih perlu dilakukan penelitian lain yang menguji bakteri golongan Gram (+) dan Gram (-) lainnya.

\section{KESIMPULAN DAN SARAN KESIMPULAN}

Dari hasil penelitian dapat disimpulkan bahwa dekok bunga belimbing wuluh efektif sebagai antimikroba terhadap bakteri Salmonella typhi secara in vitro, makin tinggi konsentrasi dekok bunga belimbing wuluh maka semakin rendah pertumbuhan bakteri Salmonella typhi dan Kadar Hambat Minimum (KHM) larutan dekok bunga belimbing wuluh terhadap bakteri Salmonella typhi pada konsentrasi $10 \%$, sedangkan Kadar Bunuh Minimum (KBM) larutan dekok bunga belimbing wuluh terhadap bakteri Salmonella typhi adalah pada konsentrasi $12,5 \%$

\section{SARAN}

Setelah terbukti bahwa dekok bunga belimbing wuluh efektif sebagai antimikroba terhadap bakteri Salmonella typhi secara in vitro, maka dapat disarankan Perlu adanya penelitian lebih lanjut mengenai bahan aktif di dalam bunga belimbing wuluh terutama yang berefek sebagai antimikroba, agar diperoleh bentuk sediaan isolasi murni dari bahan aktif tersebut serta diperlukan penelitian secara in vivo untuk mengetahui berapa dosis yang aman untuk dikonsumsi sebagai antimikroba alternatif yang disebabkan oleh infeksi bakteri Salmonella typhi.

\section{DAFTAR KEPUSTAKAAN}

1. Achmadi UF. Waspadai Sakit Saluran Pencernaan. Pikiran Rakyat. 2003 http://www.pikiran-rakyat.com/cetak/0703/05/0307.htm [akses 15 Mei 2004].

2. Zulkarnaen I. Antibiotik Dosis Tunggal Pada Demam Tifoid. Simposium Current Diagnosis and Treatment. 2001 http://www.interna.fk.ui.ac.id/artikel/current2001/ctt01_20.htm [akses 15 Mei 2004].

3. Sya'roni A. Perkembangan Penatalaksanaan Demam Tifoid. Smart Doctor. 2002. http://b.domaindlx.com/smartdoctor/software/utama/news item.asp?NewsID=28 [akses 15 Mei 2004].

4. Jamal S. Deskripsi Penyakit Sistem Sirkulasi: Penyebab Kematian Utama di Indonesia. Badan Penelitian danPengembangan Kesehatan. Cermin Dunia Kedokteran. Jakarta; 2004; 6.

5. Salsa. Belimbing Wuluh Obat Batuk. Jokam My Salsabilla. 2003. http://members.lycos.co.uk/mysalsabilla/forum/vewthread.php?tid=64 [akses 14 Pebruari 2004].

6. Mursito B. Ramuan Tradisional Untuk Pengobatan Jantung. Jakarta: Penebar Swadaya; 2002; 47-48.

7. Cakrawala-IPTEK. Belimbing Wuluh. IPTEKnet. 2004. http://iptek.net.id/cakra_obat/tanamanobat.php?1d=69 [akses 14 Pebruari 2004].

8. Indra. Penelitian Experimental dalam: Buku Ajar Metodologi Penelitian. seri I. Malang: Fakultas Kedokteran Universitas Brawijaya; 1999; 25.

9. Martin EW, Cook EF, Leuvallen EE, Osol A., Tice LF, Van Matrer CT. Remington's Practice of Pharmacy (R.P.P.XII) $12^{\text {th }}$ edition. Easton Pennsylvania: Mack Publishing Company; 1961; 308-309.

10. Murray PR, Baron EJ, Pfalier MA, Tenover FC, Yolken RH. Manual of Clinical Microbiology $7^{\text {th }}$ edition. American Society for Microbiology. Washington DC: ASM Press; 1999; 517-522, 1526-1541

11. Finegold MS, Baron JE. Bailey and Scott's Diagnostic Microbiology, 7th Ed. Toronto: Mosby Company; 1986; 183.

12. Srimulyani, Gunawan D. Ramuan Tradisional Untuk Penderita Asma. Jakarta: Penebar Swadaya; 2001; 84-87

13. Robinson T. Kandungan Organik Tumbuhan Tinggi. Edisi ke-6. Department of biochemistry University of Massachussets. Bandung: Penerbit ITB; 1995; 156,157,196

14. Cheeke PR. Saponins: Suprising Benefits of Desert Plants. The Linus Pauling Institute. 2003. http://lpi.oregonstate.edu/spsu98/saponins.html [akses 1 Juni 2004].

15. Venturella VS. Natural Product. In: GardnerH, (Ed). Remington. The Science and Practice of Pharmacy $20^{\text {th }}$ edition. Philadelphia: Lippincott Williams and Wilkins; 2000; 675-683.

16. Poespitaningtyas E. Uji Efektifitas Dekok Bunga Belimbing Wuluh (Averrhoa bilimbi L.) sebagai Antimikroba terhadap Bakteri Pseudomonas aeruginosa secara in vitro. Tugas Akhir FKUB. Malang; 2004.

17. Wibisono A. Uji Effektifitas Antimikroba Dekok Bunga belimbing Wuluh (Averrhoa bilimbi L.) terhadap Bakteri Escherichia Coli secara in vitro. Tugas Akhir FKUB. Malang; 2004. 